\title{
Nephritogenic Properties of Nephrotoxic Guinea Pig Antibodies
}

\section{Glomerulonephritis induced by Guinea Pig $\mathrm{IgG}_{1}$ Antibody in Rats}

\author{
Y. Kobayashi*, H. Shigematsu** and T. Tada**
}

Department of Medicine, School of Medicine, Kitasato University, Kanagawa, Japan* Department of Pathology, School of Medicine, Chiba University, Chiba, Japan**

Received July 30, 1973

Summary. Guinea pig $\mathrm{IgG}_{1}$ and $\mathrm{IgG}_{2}$ were separated from guinea pig antisera against rat kidney using DEAE column chromatography with gradient elution. In vitro system, nephrotoxic $\operatorname{IgG}_{1}$ antibody did not fix rat complement with rat kidney sediments, but did $\operatorname{IgG}_{2}$. Nephrotoxic $\mathrm{IgG}_{1}$ or $\mathrm{IgG}_{2}$ was intravenously injected into rats respectively. Glomerulonephritis characterized by an immediate massive proteinuria was initiated by nephrotoxic $\mathrm{IgG}_{1}$ antibody. Marked intraluminal fibrin formation and phagocytic accumulation of small numbers of neutrophiles and monocytes were observed in the glomeruli. Rat $\beta 1 \mathrm{c}$ globulin was only weakly seen along glomerular basement membrane of the biopsy specimens early in the development of nephritis. On the other hand, rats given a comparable dose of nephrotoxic $\mathrm{IgG}_{2}$ antibody did not develop a significant proteinuria and glomerular changes despite localization of $\mathrm{IgG}_{2}$ and rat $\beta 1 \mathrm{c}$ in the glomeruli. These observations suggest that non-complement mediated glomerular injury is present at least in the initial phase of Masugi nephritis.

In the past few years, two classes of $7 \mathrm{~S}$ immunoglobulins $\left(\operatorname{IgG}_{1}\right.$ and $\left.\operatorname{IgG}_{2}\right)$ have been described and characterized in the guinea pig. The $\operatorname{IgG}_{1}$ and $\operatorname{IgG}_{2}$ immunoglobulins have different electrophoretic mobilities (Benacerraf et al., 1963) and different biologic properties: $\operatorname{IgG}_{1}$ antibody has a capacity to sensitize guinea pig for passive cutaneous or systemic anaphylaxis (Ovary et al., 1963), but is incapable of fixing complement and lysing red blood cells (Bloch et al., 1963; Kourilsky et al., 1963). $\mathrm{IgG}_{2}$, on the other hand, has been known to fix complement, lyse cells and be capable of provoking Arthus reaction, but not passive anaphylactic reaction.

Meanwhile, as to the mechanisms of the initiation of Masugi nephritis, a sequence of immunobiological events has been noticed. Especially, there is a general agreement that participation of the complement-leucocyte system is essential for initiation of glomerulonephritis (Cochrane et al., 1965; Cochrane, 1969). On the other hand, it is found that rats injected with duck nephrotoxic antibodies developed an immediate proteinuria, despite little or no fixation of C3 (Unanue and Dixon, 1964) and the absence of neutrophile accumulation (Cochrane, 1965). Some experiments are also reported that Masugi nephritis could be induced in complement deficient rabbits (Rother et al., 1967) and complement deficient mice (Unanue et al., 1967).

The present investigation was undertaken to study further the immunobiological properties of the initiation of Masugi nephritis, using nephrotoxic guinea pig $\mathrm{IgG}_{1}$ antibody which is found to be incapable of fixing complement in the classical pathway. Nephritogenicity of nephrotoxic $\operatorname{IgG}_{\mathbf{2}}$ antibody is also described. 


\section{Materials and Methods}

Animals. Wistar rats of either sex weighing 150 to $200 \mathrm{~g}$ were used.

Antigens. Renal antigen for immunization was prepared by the method described by Fujimoto et al. (1964). Renal cortices were obtained from perfused rat kidneys and ground in a Waring blendor. A $10 \% \mathrm{w} / \mathrm{v}$ suspension was prepared in saline. Soluble antigen of kidney was prepared by trypsinization of kidney sediment by the method of Cole (1951).

Preparation of Nephrotoxic Serum. Guinea pigs weighing 500 to $600 \mathrm{~g}$ were injected in footpads with $0.5 \mathrm{mgN}$ of the antigen in an equal volume of incomplete Freund's adjuvant, followed by seven biweekly injections of the same antigen into the back muscle. They were bled 2 weeks after the last injection. Sera were absorbed with packed rat erythrocytes and a small quantity of rat serum until no hemagglutination and precipitin reactions were detected.

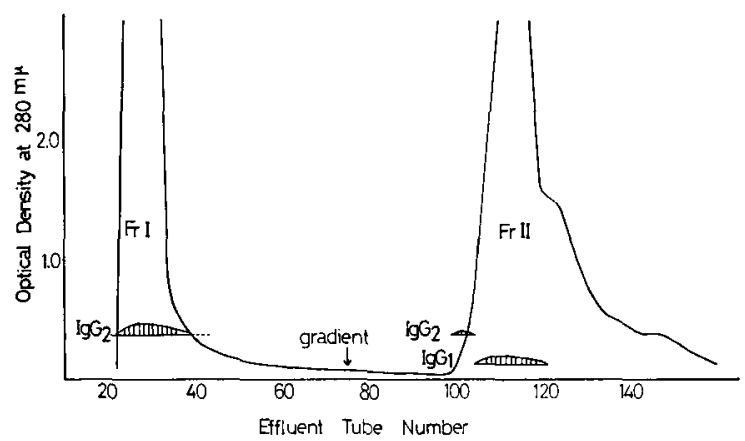

Fig. 1. A chromatographic pattern of $40 \%$ ammonium sulfate precipitate on DEAE cellulose column using gradient elution from $0.005 \mathrm{M}, \mathrm{pH} 8.5$ to $0.59 \mathrm{M}, \mathrm{pH} 4.0$ phosphoric acid-Tris buffers. $\operatorname{IgG}_{1}$ fraction was mostly eluted in the second peak

Purification of $I g G_{1}$ and $I g G_{2}$ Fractions from Nephrotoxic Sera. Purification of immunoglobulin fractions was carried out according to the method described by Yagi et al. (1962) with diethylaminoethyl (DEAE) cellulose column chromatography. The serum was precipitated at $40 \%$ saturation of ammonium sulfate, and the precipitate was dissolved and dia. lyzed against $0.15 \mathrm{M}$ saline and then a buffer consisting of $0.035 \mathrm{M}$ Tris (hydroxymethyl) aminomethane (Tris) and $0.005 \mathrm{M}$ phosphoric acid, $\mathrm{pH}$ 8.5. An aliquot of the sample was applied to a DEAE cellulose column which had been equilibrated with the same buffer. After the first peak was completely eluted with the buffer, the $\mathrm{pH}$ and salt gradient elution was started using the final buffer consisting of $0.5 \mathrm{M}$ Tris and $0.59 \mathrm{M}$ phosphoric acid, $\mathrm{pH} 4.0 . \mathrm{IgG}_{2}$ was eluted in the first peak. The second peak contained most of $\operatorname{IgG}_{1}$ (Fig. 1). When some contamination of $\operatorname{IgG}_{2}$ was detected by immunoelectrophoresis, rechromatography of $\operatorname{IgG}_{1}$ fraction was performed by the same procedure to devoid $\mathrm{IgG}_{2}$. The preparation of $\mathrm{IgG}_{1}$ fraction thus obtained was then passed through a Sephadex G 200 column $(2.5 \times 100 \mathrm{~cm})$ to eliminate the possible contamination of IgM. The final preparation contained $\operatorname{IgG}_{1}$ together with some $\alpha$ and $\beta$ globulins.

Antisera. Anti-guinea pig $I g G_{1}$. Rabbit antibody specific for guinea pig $\operatorname{IgG}_{1}$ was prepared by immunizing a rabbit with $\operatorname{IgG}_{1}$ antibody specifically purified from hyperimmune guinea pig serum against hen's egg albumin (EA). Hyperimmune guinea pig serum was pooled and anti-EA was purified specifically by the method of Hong et al. (1965). The purified antibody containing guinea pig $\operatorname{IgG}_{1}$ and $\operatorname{IgG}_{2}$ was subjected to Starch block electrophoresis according to the method of Kunkel (1954). The fractions containing only $\operatorname{IgG}_{1}$ were pooled, concentrated and used for the immunization of a rabbit. A rabbit received four injections of $400 \mu \mathrm{gN}$ of this material emulsified in an equal volume of complete Freund's adjuvant with biweekly intervals and was bled 2 weeks after the last injection. This antiserum was absorbed with purified $\mathrm{IgG}_{2}$ and was referred as anti- $\operatorname{IgG}_{1}$. 
Anti-Guinea Pig $I g G_{2}$. Normal $\mathrm{IgG}_{2}$ for the immunization was prepared from normal guinea pig serum by the same chromatographic method as described above. Antiserum against $\mathrm{IgG}_{2}$ was prepared by the same immunization procedure used for the preparation of antiguinea pig $\operatorname{IgG}_{1}$. The antiserum was absorbed with $\operatorname{IgG}_{1}$ to render specific for $\operatorname{IgG}_{2}$.

Anti-Rat $\beta 1 \mathrm{c}$ Globulin. The antiserum against rat $\beta 1 \mathrm{c}$ was prepared using zymosan according to the method described by Mardiney and Müller-Eberhard (1965).

Immunoelectrophoresis. Immunoelectrophoresis was carried out according to the method of Scheidegger (1955).

Quantitation of Kidney Fixing Antibody (KFAbs) in Nephrotoxic IgG and IgG Fractions in vivo. Radioiodination of $\operatorname{IgG}_{1}$ and $\mathrm{IgG}_{2}$ was carried out according to the method of Day et al. (1956). After extensive dialysis, the nitrogen content of the iodinated protein was estimated by nesslerization and its specific activity was determined. To calculate the rate of fixation of each nephrotoxic fraction to the kidneys and other organs, $150 \mu \mathrm{gN}$ of $\mathrm{I}^{131}$ labeled antibodies were injected into groups of 3 rats. Estimation of the radioactivity in each organ was carried out by the method described by Bale and Spar (1954). As 90 per cent or more of nephrotoxic antibodies are fixed to GBM within 1 hour after intravenous injection (Unanue and Dixon, 1965), all rats were sacrified at 1 hour after the injection and organs were perfused with saline. Organs removed from the animals were blotted with filterpaper to remove excess fluids, and placed into test tubes which were then inserted into a well-type scintillation counter. The counts were corrected with background and decay of $I^{131}$. As a control, $100 \mu \mathrm{gN}$ of $\mathrm{I}^{131}$ labeled normal guinea pig $\operatorname{IgG}_{1}$ and $\mathrm{IgG}_{2}$ were injected to groups of 3 rats and the degree of non-specific localization of immunoglobulins to various organs was estimated in a similar manner.

Complement Fixation Tests. Two-dimensional complement fixation tests were carried out by the method of Mayer (1961). Equal volumes $(0.4 \mathrm{ml})$ of rat kidney sediments, nephrotoxic $\mathrm{IgG}_{1}$ or $\mathrm{IgG}_{2}$ antibody and $0.5 \mathrm{ml}$ of fresh rat serum containing $5 \mathrm{CH}_{50}$ units complement were incubated at $37^{\circ} \mathrm{C}$ for 1 hour. The mixture was centrifuged at $3000 \mathrm{rpm}$ for 20 minutes, and then to the supernatant, $0.2 \mathrm{ml}$ of EA containing $10^{8}$ cells were added. After incubation at $37^{\circ} \mathrm{C}$ for 1 hour the degree of hemolysis was read macroscopically.

Induction of Glomerulonephritis by Nephrotoxic IgG $G_{1}$ Antibody. Rats with urinary protein less than $1.0 \mathrm{mg} / 24 \mathrm{hr}$ were used for the experiments. Nephritis was induced by a single intravenous injection of various amounts of $\mathrm{IgG}_{1}$ or $\mathrm{IgG}_{2}$ antibody. The amounts of urinary protein during $24 \mathrm{hr}$ period were estimated according to the Kingsbury-Clark's method. In order to follow the dynamics of renal lesions, renal biopsy and autopsy were carried out at various times from 6 hr to 3 weeks after the injection. In control studies rats were given intravenously either $1 \mathrm{ml}$ of normal guinea pig serum or $2 \mathrm{mgN}$ of $\mathrm{IgG} \mathrm{G}_{1}$ fraetion of normal guinea pig serum.

Immunohistochemical Studies. Specimens obtained at renal biopsy and autopsy were snap frozen in liquid n-hexane at $-70^{\circ} \mathrm{C}$. Frozen sections cut at $4 \mu$ in a cryostat were stained with a fluorescent microseope (Type S-F, Nippon Kogaku). Conjugation of anti-rat $\beta 1 \mathrm{c}$, antiguinea pig $\mathrm{IgG}_{1}$ and anti-guinea pig $\mathrm{IgG}_{2}$ with Fluorescein isothiocyanate (FITC) was carried out according to the method of Wood et al. (1965). As controls of fixation of rat $\beta 1 \mathrm{c}$ in glomeruli, the blocking test was performed and normal rat kidney was stained with FITC-conjugated anti-rat $\beta 1 \mathrm{c}$.

Histological Studies. For electron microscopy small blocks obtained at renal biopsy and autopsy were immersed in $3 \%$ glutaraldehyde in $0.1 \mathrm{M}$ phosphate buffer, $\mathrm{pH} 7.4$ for 1 to $2 \mathrm{hr}$ at $4^{\circ} \mathrm{C}$. The tissues were then post-fixed in $1 \%$ osmium tetroxide in $0.1 \mathrm{M}$ phosphate buffer of pH 7.4 for $1.5 \mathrm{hr}$. After dehydration with graded ethanol, they were embedded in Epon 812 . The ultrathin sections were cut on a Porter-Blum MT-1 microtome, doubly stained with uranyl acetate and lead citrate, and examined with a Hitachi HS-8 or 11Ds electron microscope. Semithin sections $(1 \mu)$ were stained with PAS and Toluidine blue after removing the resin by the method by Imai et al. (1968) for light microscopic examination. Other tissue blocks were fixed in $10 \%$ formalin and embedded in paraffin for usual microscopic examination.

\section{Results}

Purity of $I g G_{1}$ Fraction. The purity of the final preparation of nephrotoxic $\mathrm{IgG}_{1}$ fraction was tested by immunoelectrophoresis. As shown in Fig. 2, the 


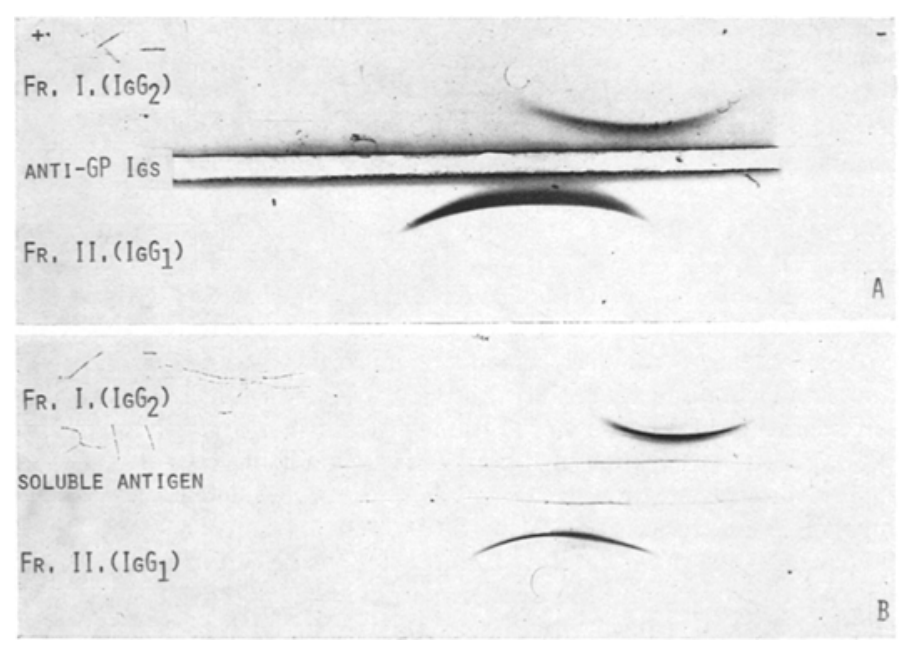

Fig. 2. Immunoelectrophoresis analyses of $\mathrm{IgG}_{1}$ and $\mathrm{IgG}_{2}$ fractions. $500 \mu \mathrm{gN}$ of $\mathrm{IgG}_{1}$ or $\mathrm{IgG}_{2}$ fraction was applied into each well. $\operatorname{IgG}_{1}$ fraction shows a precipitin band in the $\gamma 1$ region $(1-a)$. This $\operatorname{IgG}_{1}$ fraction developed with soluble kidney antigen forms a single distinct precipitin line corresponding to $\gamma 1$ region but not $\gamma^{2}(1-b)$

Table 1. Localization of $\mathrm{I}^{131}$-nephrotoxic $\operatorname{IgG}_{1}$ and $\operatorname{IgG}_{2}$ antibodies to various organs in vivo

\begin{tabular}{|c|c|c|c|c|c|c|c|}
\hline \multirow[t]{2}{*}{ Materials injected } & \multirow{2}{*}{$\begin{array}{l}\text { Doses } \\
\text { injec- } \\
\text { ted } \\
(\mu \mathrm{gN})\end{array}$} & \multicolumn{6}{|c|}{ Per cent localized } \\
\hline & & Kidney & Heart & Lung & Liver & Spleen & Blood $^{a}$ \\
\hline Nephrotoxic $\operatorname{IgG}_{1}$ fr. ${ }^{b}$ & 150 & $\begin{array}{l}2.536 \\
\pm 0.511\end{array}$ & $\begin{array}{l}0.078 \\
\pm 0.017\end{array}$ & $\begin{array}{l}0.569 \\
\pm 0.104\end{array}$ & $\begin{array}{l}9.303 \\
\pm 1.297\end{array}$ & $\begin{array}{l}0.830 \\
\pm 0.091\end{array}$ & $\begin{array}{l}2.714 \\
\pm 0.073\end{array}$ \\
\hline Normal $\mathrm{IgG}_{1}$ fr. & 100 & $\begin{array}{l}1.625 \\
\pm 0.354\end{array}$ & $\begin{array}{l}0.044 \\
\pm 0.014\end{array}$ & $\begin{array}{l}0.171 \\
\pm 0.112\end{array}$ & $\begin{array}{l}5.721 \\
\pm 1.228\end{array}$ & $\begin{array}{l}0.190 \\
\pm 0.019\end{array}$ & $\begin{array}{l}3.385 \\
\pm 0.145\end{array}$ \\
\hline Nephrotoxic $\operatorname{IgG}_{2}$ & 150 & $\begin{array}{l}2.338 \\
\pm 0.150\end{array}$ & $\begin{array}{l}0.093 \\
\pm 0.012\end{array}$ & $\begin{array}{l}2.003 \\
\pm 1.227\end{array}$ & $\begin{array}{l}13.202 \\
\pm 2.988\end{array}$ & $\begin{array}{l}0.743 \\
\pm 0.135\end{array}$ & $\begin{array}{l}1.958 \\
\pm 0.139\end{array}$ \\
\hline Normal $\mathrm{IgG}_{2}$ & 100 & $\begin{array}{l}0.725 \\
\pm 0.091\end{array}$ & $\begin{array}{l}0.016 \\
\pm 0.006\end{array}$ & $\begin{array}{l}0.113 \\
\pm 0.035\end{array}$ & $\begin{array}{l}4.700 \\
\pm 0.311\end{array}$ & $\begin{array}{l}0.139 \\
\pm 0.042\end{array}$ & $\begin{array}{l}1.636 \\
\pm 0.190\end{array}$ \\
\hline
\end{tabular}

All results are average of 3 rats. Localization of each fraction to tissues was estimated at 1 hour after injection.

a Values are percent dose in $1 \mathrm{ml}$ of blood.

b $\mathrm{IgG}_{1}$ fraction.

fraction, $500 \mu \mathrm{gN}$ of which were applied into a well, showed an only precipitin band in the $\gamma l$ region with rabbit anti-guinea pig immunoglobulins in the immunoelectrophoresis. When the preparation was subjected to the immunoelectrophoresis with soluble antigen of trypsin digested kidney sediments, a precipitin band having a distinctly fast electrophoretic mobility developed. These results imply that the $\operatorname{IgG}_{1}$ fraction contained mainly $\operatorname{IgG}_{1}$ and the contamination of $\mathrm{IgG}_{2}$ is negligible. 
Table 2. Two-dimensional complement fixation tests with rat kidney sediments and nephrotoxic $\operatorname{IgG}_{1}$ and $\operatorname{IgG}_{2}$ antibodies

$\mathrm{IgG}_{1}$ antibody system

\begin{tabular}{llllllll}
\hline $\begin{array}{l}\operatorname{IgG}_{1} \\
(\mu g N)\end{array}$ & \multicolumn{7}{c}{ Rat kidney sediments $(\mu \mathrm{gN})$} \\
\cline { 2 - 8 } & 100 & 50 & 25 & 12.5 & 6.25 & 3.13 & 0 \\
\hline 10 & $2^{\mathrm{a}}$ & 3 & 4 & 4 & 4 & 4 & 4 \\
5 & 2 & 4 & 4 & 4 & 4 & 4 & 4 \\
2.5 & 2 & 4 & 4 & 4 & 4 & 4 & 4 \\
1.25 & 2 & 4 & 4 & 4 & 4 & 4 & 4 \\
0.63 & 2 & 4 & 4 & 4 & 4 & 4 & 4 \\
0 & 2 & 4 & 4 & 4 & 4 & 4 & 4 \\
\hline
\end{tabular}

$\mathrm{IgG}_{2}$ antibody system

\begin{tabular}{|c|c|c|c|c|c|c|c|}
\hline \multirow{2}{*}{$\begin{array}{l}\mathrm{IgG}_{2} \\
(\mu \mathrm{gN})\end{array}$} & \multicolumn{7}{|c|}{ Rat kidney sediments $(\mu \mathrm{gN})$} \\
\hline & 100 & 50 & 25 & 12.5 & 6.25 & 3.13 & 0 \\
\hline 10 & 0 & 0 & 1 & 1 & 2 & 2 & 4 \\
\hline 5 & 0 & 1 & 2 & 3 & 4 & 4 & 4 \\
\hline 2.5 & 1 & 2 & 3 & 3 & 4 & 4 & 4 \\
\hline 1.25 & 1 & 3 & 3 & 4 & 4 & 4 & 4 \\
\hline 0.63 & 2 & 3 & 4 & 4 & 4 & 4 & 4 \\
\hline 0 & 2 & 4 & 4 & 4 & 4 & 4 & 4 \\
\hline
\end{tabular}

Dotted line represents zone of complement fixation. 0 means no lysis, 4 means complete lysis.

a Anti-complementary effect.

Quantitation of Kidney Fixing Antibodies. The $\mathrm{IgG}_{1}$ fraction was tested for its kidney fixing activity by the method described above. As shown in Table 1, 0.91 per cent of nephrotoxic $\operatorname{IgG}_{1}$ fraction was fixed specifically to the kidney during $1 \mathrm{hr}$ after the intravenous injection. On the other hand, 1.6 per cent of nephrotoxic $\mathrm{IgG}_{2}$ was fixed to the kidney. It is worthy of note that 1.9 per cent of nephrotoxic $\operatorname{IgG}_{2}$ which was over the dose of kidney fixing $\operatorname{Ig} \mathrm{G}_{2}$ was fixed to the lung, while only 0.4 per cent of nephrotoxic $\operatorname{IgG}_{1}$ was.

Complement Fixation Tests. Table 2 shows the results of two-dimentional complement fixation tests. In $\mathrm{IgG}_{1}$ antibody system, $\operatorname{IgG}_{1}$ antibody did not fix rat complement at all, whereas $\operatorname{IgG}_{2}$ did in $\operatorname{IgG}_{2}$ system.

Induction of Glomerulonephritis by Nephrotoxic IgG $G_{1}$ Antibody. Table 3 represents the results of urinalysis in the rats with nephrotoxic $\operatorname{IgG}_{1}$ fraction. All rats given more than $1 \mathrm{mgN}$ of nephrotoxic $\operatorname{IgG}_{1}$ containing $9.1 \mu \mathrm{gN}$ or more of KFAbs developed an immediate proteinuria within $24 \mathrm{hr}$ after the injection. Especially in rats injected with more than $2.7 \mathrm{mgN}$ of nephrotoxic $\operatorname{IgG}_{1}$, a massive proteinuria during the first $24 \mathrm{hr}$ appeared. This proteinuria persisted for 2 to 3 months of the observation period. On the other hand, rats given less than $1.5 \mathrm{mgN}$ of 
Table 3. Induction of glomerulonephritis by nephrotoxic guinea pig $\operatorname{IgG}_{1}$ or $\operatorname{IgG}_{2}$ antibody

\begin{tabular}{|c|c|c|c|c|c|c|c|c|c|}
\hline \multirow{2}{*}{$\begin{array}{l}\text { Rat } \\
\text { No }^{a}\end{array}$} & \multirow{2}{*}{$\begin{array}{l}\text { Nephro- } \\
\text { toxic } \\
\text { immuno- } \\
\text { globu- } \\
\text { lins }\end{array}$} & \multirow{2}{*}{$\begin{array}{l}\text { Total } \\
\text { doses } \\
\text { injected } \\
(\mathrm{mgN})\end{array}$} & \multirow{2}{*}{$\begin{array}{l}\text { Amounts } \\
\text { of kidney } \\
\text { fixing } \\
\text { antibodies } \\
(\mu g N)\end{array}$} & \multirow{2}{*}{$\begin{array}{l}\text { Days } \\
\text { after } \\
\text { injec- } \\
\text { tion }\end{array}$} & \multirow{2}{*}{$\begin{array}{l}\text { Protein- } \\
\text { uria } \\
\text { (mg/day) }\end{array}$} & \multicolumn{4}{|c|}{ Immunofluorescent studies } \\
\hline & & & & & & $\mathrm{GPIgG}_{1}$ & $\mathrm{GPIgG}_{2}$ & $\operatorname{Rat} \beta 1 \mathrm{c}$ & RatIgG \\
\hline 801 & $\operatorname{IgG}_{1}$ & 13.3 & 121 & $\begin{array}{r}1 \\
14\end{array}$ & $\begin{array}{l}140 \\
256\end{array}$ & $\begin{array}{l}3+b \\
3+\end{array}$ & - & $\begin{array}{l}1+ \\
3+\end{array}$ & $\overline{3+}$ \\
\hline 802 & $\operatorname{IgG}_{1}$ & 4.0 & 36.4 & $\begin{array}{c}1 \\
\text { died } \\
\text { on } 4\end{array}$ & $\begin{array}{l}137 \\
120\end{array}$ & $\begin{array}{l}3+ \\
\text { not } \\
\text { done }\end{array}$ & - & $1+$ & - \\
\hline 851 & $\operatorname{IgG} G_{1}$ & 2.7 & 24.6 & $\begin{array}{r}1 \\
14\end{array}$ & $\begin{array}{r}66 \\
210\end{array}$ & $\begin{array}{l}3+ \\
3+\end{array}$ & - & $\begin{array}{l}1+ \\
3+\end{array}$ & $\overline{3+}$ \\
\hline 803 & $\operatorname{IgG}_{1}$ & 1.0 & 9.1 & $\begin{array}{r}1 \\
14\end{array}$ & $\begin{array}{r}11.5 \\
5.0\end{array}$ & $\begin{array}{l}3+ \\
3+\end{array}$ & - & $\begin{array}{l}1+ \\
3+\end{array}$ & $\overline{3+}$ \\
\hline 813 & $\operatorname{IgG}_{2}$ & 2.6 & 41.6 & $\begin{array}{l}\text { died at } \\
20 \mathrm{~min}\end{array}$ & & $\begin{array}{l}\text { not } \\
\text { done }\end{array}$ & & & \\
\hline 814 & $\operatorname{Ig} G_{2}$ & 1.9 & 30.6 & $\begin{array}{l}\text { died at } \\
30 \mathrm{~min}\end{array}$ & & $\begin{array}{l}\text { not } \\
\text { done }\end{array}$ & & & \\
\hline 811 & $\operatorname{IgG} G_{2}$ & 1.5 & 24.2 & $\begin{array}{l}1 \\
9\end{array}$ & $\begin{array}{l}0.4 \\
0.1\end{array}$ & $\overline{-}$ & $\begin{array}{l}3+ \\
3+\end{array}$ & $\begin{array}{l}3+ \\
3+\end{array}$ & $\overline{3+}$ \\
\hline 815 & $\operatorname{IgG}_{2}$ & 1.1 & 17.7 & $\begin{array}{r}1 \\
14\end{array}$ & $\begin{array}{l}0.1 \\
0.6\end{array}$ & - & $\begin{array}{l}3+ \\
3+\end{array}$ & $\begin{array}{l}3+ \\
3+\end{array}$ & $\overline{3+}$ \\
\hline
\end{tabular}

a These rats included in Table 3 are representative cases.

b Grade $(3+)$ to $(-)$ represents the intensity of fluorescene in glomeruli.

nephrotoxic $\mathrm{IgG}_{2}$ containing $24.2 \mu \mathrm{gN}$ of $\mathrm{KFAbs}$ survived but did not develop a significant proteinuria. Furthermore, if rats were given $30.6 \mu \mathrm{gN}$ or more of $\mathrm{KFAbs}$ of $\mathrm{IgG}_{2}$, they all died of the acute pulmonary edema within $1 \mathrm{hr}$ after the injection as seen in rats given large amounts of nephrotoxic rabbit IgG (Shigematsu and Kobayashi, 1972).

Immunohistochemical Studies. In biopsy specimens obtained between 6 to $24 \mathrm{hr}$ after the injection of nephrotoxic $\operatorname{IgG}_{1}, \mathrm{IgG}_{\mathbf{1}}$ was observed to be localized along GBM in a linear pattern (Fig. 3), whereas $\operatorname{IgG}_{2}$ was not detected. Rat $\beta 1 \mathrm{c}$ globulin was seen only weakly and usually locally along the same site in a linear pattern (Fig. 4). In the blocking test, rat $\beta$ tc was negative in glomeruli of these biopsy specimens. In the survied group of rats given nephrotoxic $\operatorname{IgG}_{2}, \operatorname{IgG}_{2}$ together with $\beta 1 \mathrm{c}$ was distinctly stained despite no proteinuria and little histologic changes.

Histological Findings. As early as $6 \mathrm{hr}$ after the injection, the glomerular endothelial linings detached themselves broadly from the basement membrane (Fig. 5).

At the same time small numbers of migrant neutrophiles and/or monocytes accumulated locally in the glomerular loops, particularly in their peripheral parts (Fig. 5, 8). Local fusions of epithelial foot processes were also seen. In the $24 \mathrm{hr}$ biopsy specimen an accumulation of the materials with a staining property of fibrin was prominent in the glomeruli (Fig. 6). The fibrin mass often clung to the 

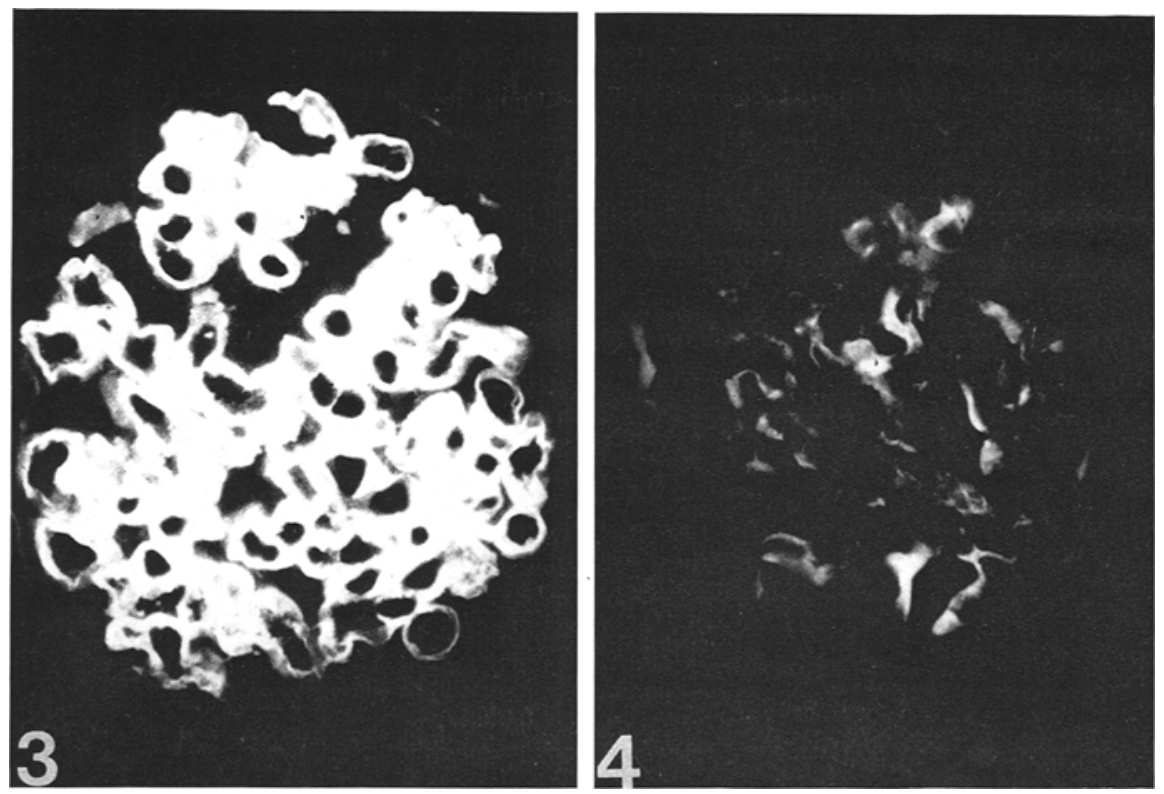

Fig. 3. Fluorescent micrograph of a glomerulus from the biopsy specimen obtained $24 \mathrm{hr}$ after the injection of $\mathrm{NTIgG}_{1}$. Guinea pig $\operatorname{IgG}_{1}$ is brilliantly seen along GBM in a linear pattern

Fig. 4. Fluorescent micrograph of a glomerulus from the same specimen as that of Fig. 3 Rat $\beta 1 \mathrm{c}$ globulin is slightly seen along GBM

basement membrane and some capillary lumina were entirely occupied by these materials. In such areas the endothelial linings were usually absent or lifted up by the depositions of fibrinoid material (Fig. 9). Cell debris or osmiophilic granular materials were intermingled with the fibrin masses. The glomerular changes on the 2 to 3 day were similar to those found in the $24 \mathrm{hr}$-biopsy specimen, but, at this stage, infiltration of small numbers of monocytes or macrophages were noted in the glomeruli. Some glomerular loops were occluded by massive fibrin thrombi with an occasional partial necrosis of the glomerular tissues. Eleven to 14 days after the injection, the thrombotic changes of the glomeruli rather regressed, but the persistence of fibrinoid materials was still observed in the loops in varying degrees. The glomerular capillary wall showed local edematous thickening with the moderate increase of the mesangial matrix (Fig. 7).

\section{Discussion}

Present investigation demonstrated that glomerulonephritis characterized by massive formation of fibrin in the glomerular capillary lumen with minimum phagocytic reaction was induced by nephrotoxic guinea pig $\operatorname{IgG}_{1}$ fraction.

It is reported that guinea pig $\mathrm{IgG}_{2}$ antibody is capable of fixing complement and provoking passive Arthus reaction, whereas $\operatorname{IgG}_{1}$ antibody is not (Bloch et al., 1963). A question arises as to whether the glomerulonephritis induced by nephro- 

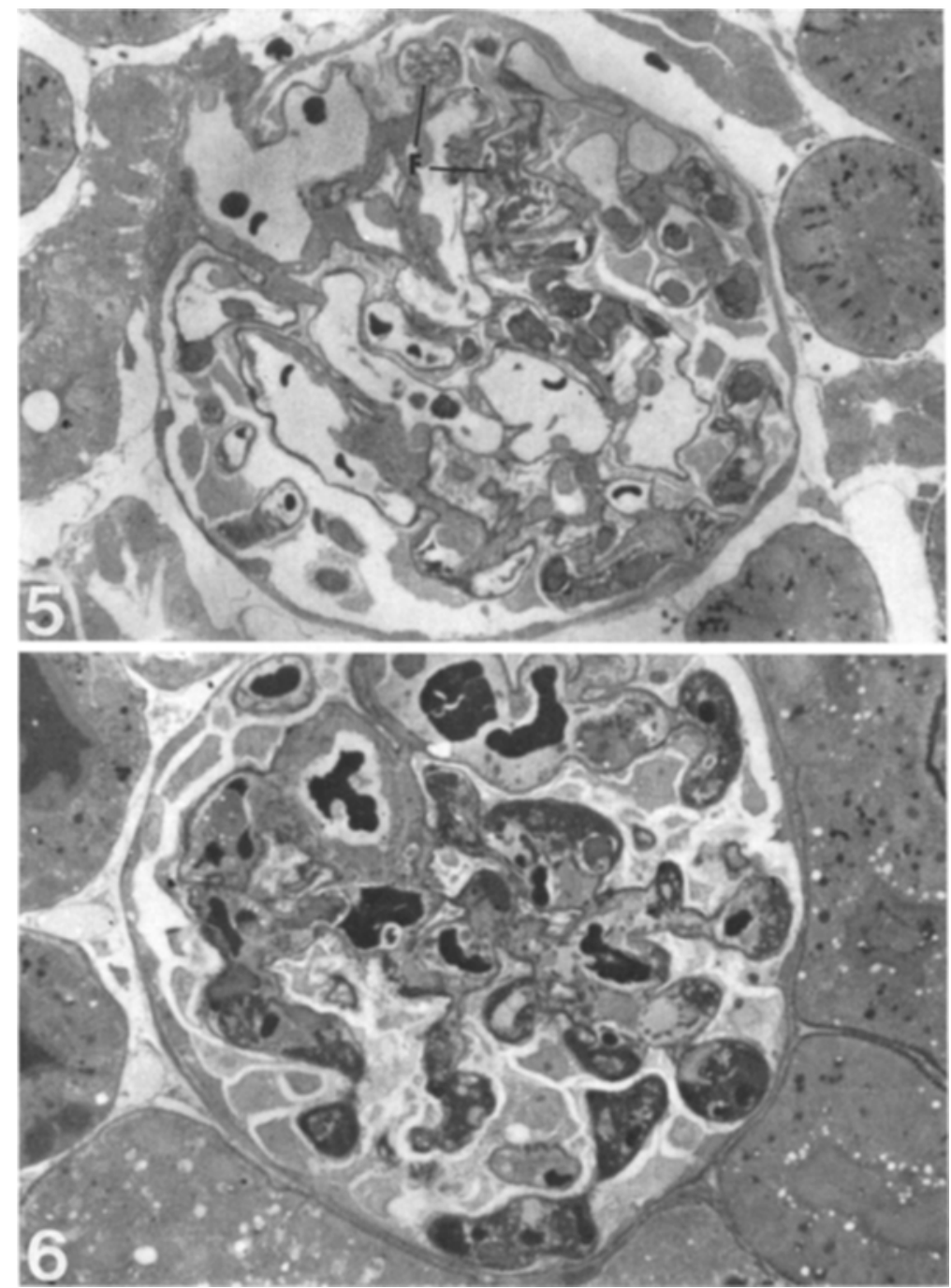

Fig. $5.6 \mathrm{hr}$ after the injection. Focal accumulation of neutrophiles in the peripheral capillary loops. Fibrin $\left(F^{\prime}\right)$ is also observed in the capillary lumen. PAS and toluidine blue. $650 \times$

Fig. 6. $24 \mathrm{hr}$ after the injection. Massive intravascular fibrin formation is found in the peripheral part of the capillary loops. PAS and Toluidine blue. $650 \times$

toxic $\mathrm{IgG}_{1}$ fraction may be caused by $\mathrm{IgG}_{2}$ antibody contaminating into $\mathrm{IgG}_{1}$ fraction. However, the contamination of $\mathrm{IgG}_{2}$ in $\mathrm{IgG}_{1}$ preparation seemed to be little, if any: In the glomerulus of biopsy specimens of rats injected with nephrotoxic $\operatorname{IgG}_{1}$ fraction, $\operatorname{IgG}_{2}$ was not detected by fluorescent antibody methods. When a rat was injected with $1.0 \mathrm{mgN}$ of nephrotoxic $\mathrm{IgG}_{1}$ fraction containing $9.1 \mu \mathrm{gN}$ of $\mathrm{KFAbs}$, it developed an immediate proteinuria, while a rat injected with $1.5 \mathrm{mgN}$ of nephrotoxic $\mathrm{IgG}_{2}$ containing $24.2 \mu \mathrm{gN}$ of KFAbs did not. These 


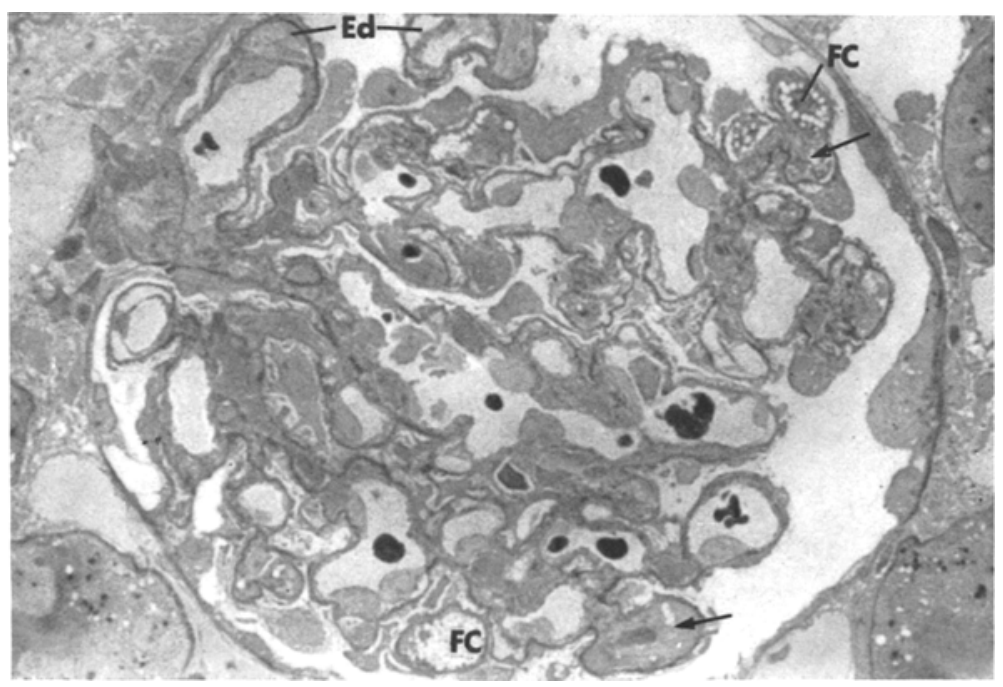

Fig. 7. 14 days after the injection. Intraluminal fibrinoid material is still present (arrows). Foam cells $(F C)$ are observed in some capillary loops. The subendothelial space is seen to be edematous (Ed). PAS and toluidine blue. $650 \times$

findings imply that nephrotoxic $\operatorname{IgG}_{1}$ antibody are res ponsible for this glomerulonephritis.

If this is so, then, the next question is posed as to whether the complement system had a share in the initiation of the glomerulonephritis by $\operatorname{IgG}_{1}$ antibody. It is unclear whether guinea pig $\operatorname{IgG}_{1}$ antibody can not fix rat complement, although it is incapable of fixing guinea pig complement in the classical sequence of reactions (Bloch et al., 1963; Keller et al., 1968). Recently, Osler et al. reported that preformed immune aggregates composed of $\mathrm{IgG}_{1}$ antibodies and antigens did interact with not only guinea pig, but also rat $\mathrm{C} 3$ and later components, despite little utilization of $\mathrm{C} 1, \mathrm{C} 4$ and $\mathrm{C} 2$, although $\mathrm{IgG}_{1}$ antibody failed to activate the complement system in the conventional assays in which the order of addition was antibody, $C$ and antigen (Osler, et al., 1969; Sandberg et al., 1970). However, the significance of the alternate pathway of complement fixation in the immunologic tissue injury is still unclear. In this experiment, nephrotoxie $\operatorname{IgG}_{1}$ antibody did not fix rat complement with rat kidney sediments, whereas $\mathrm{IgG}_{2}$ did. Moreover, in the initial glomerular changes induced by nephrotoxic $\operatorname{IgG}_{1}$, rat $\beta 1 \mathrm{c}$ was only weakly seen along GBM, and an accumulation of only small numbers of neutrophiles and monocytes was observed, while the marked intraluminal fibrin deposition was the most dramatic feature. These are apparently different from the prominent phagocytic changes in rat Masugi nephritis initiated by nephrotoxic rabbit IgG antibody with an ability of fixing complement (Shigematsu, 1970). On the basis of these results, it is probable that the characteristic changes induced by nephrotoxic $\mathrm{IgG}_{\mathbf{1}}$ antibody $1 \mathrm{~s}$ caused by non-complement mediated pathway at least in the classical sense of complement activation.

As mentioned above, the paucity of cellular reactions is another characteristic feature of $\mathrm{IgG}_{\mathbf{1}}$ nephritis. A small number of neutrophiles accumulated in the 


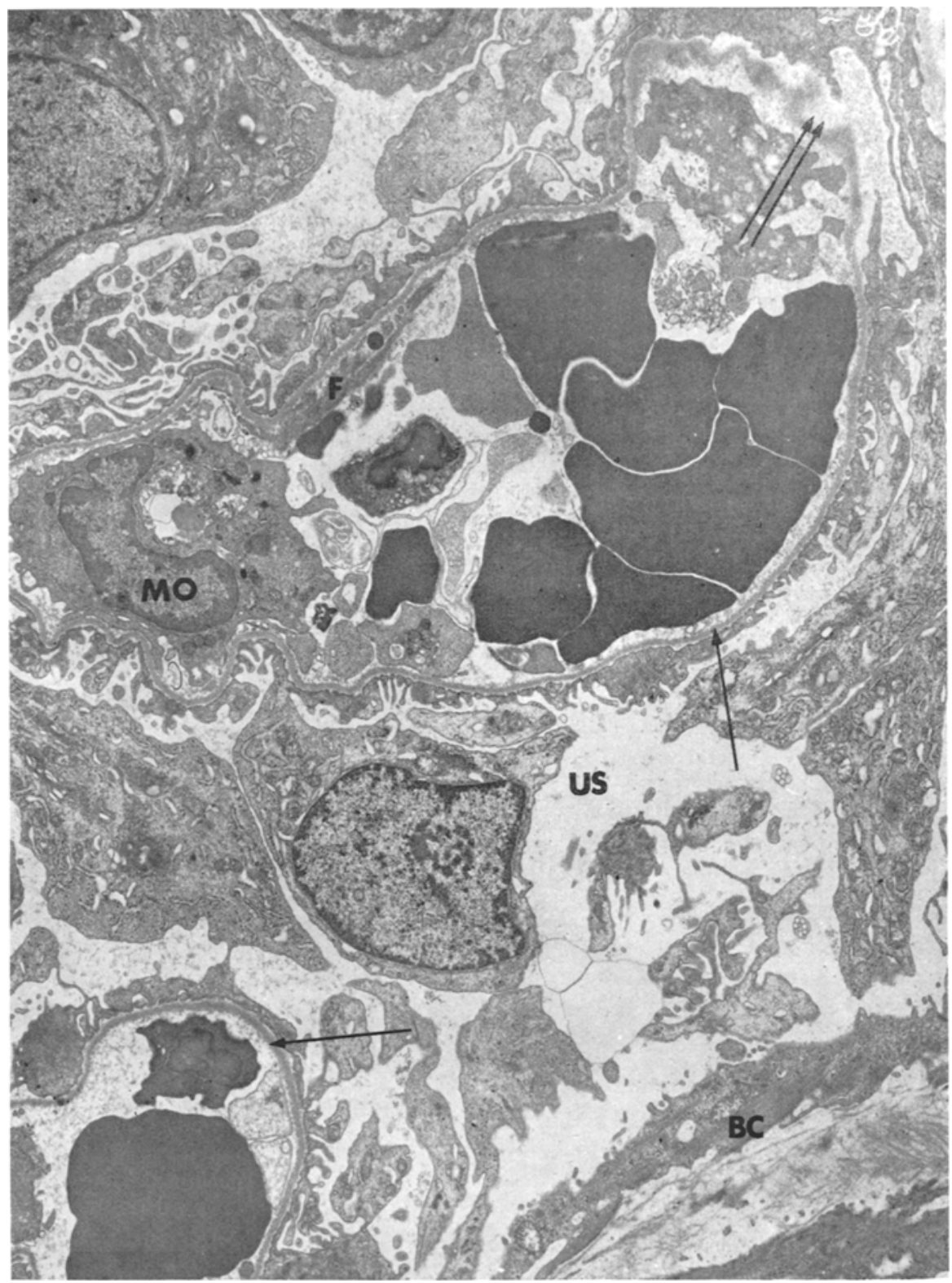

Fig. $8.6 \mathrm{hr}$ after the injection. Note broad exfoliation of endothelial lining from the glomerular basement membrane (arrow). Fibrin formation $(F)$ and migrant monocyte $(M O)$ are seen in the capillary lumen. Partial detachment of epithelial cytoplasm from the meandering basement membrane is found at double arrows. Urinary space (US) Bowmann's capsule (BC). $5200 \times$

early stage of the nephritis disappeared almost completely at $24 \mathrm{hr}$ after the injection. The number of mononuclear cells was also few which appeared instead of neutrophiles in the glomerulus. The deposition of fibrin, on the other hand, was 


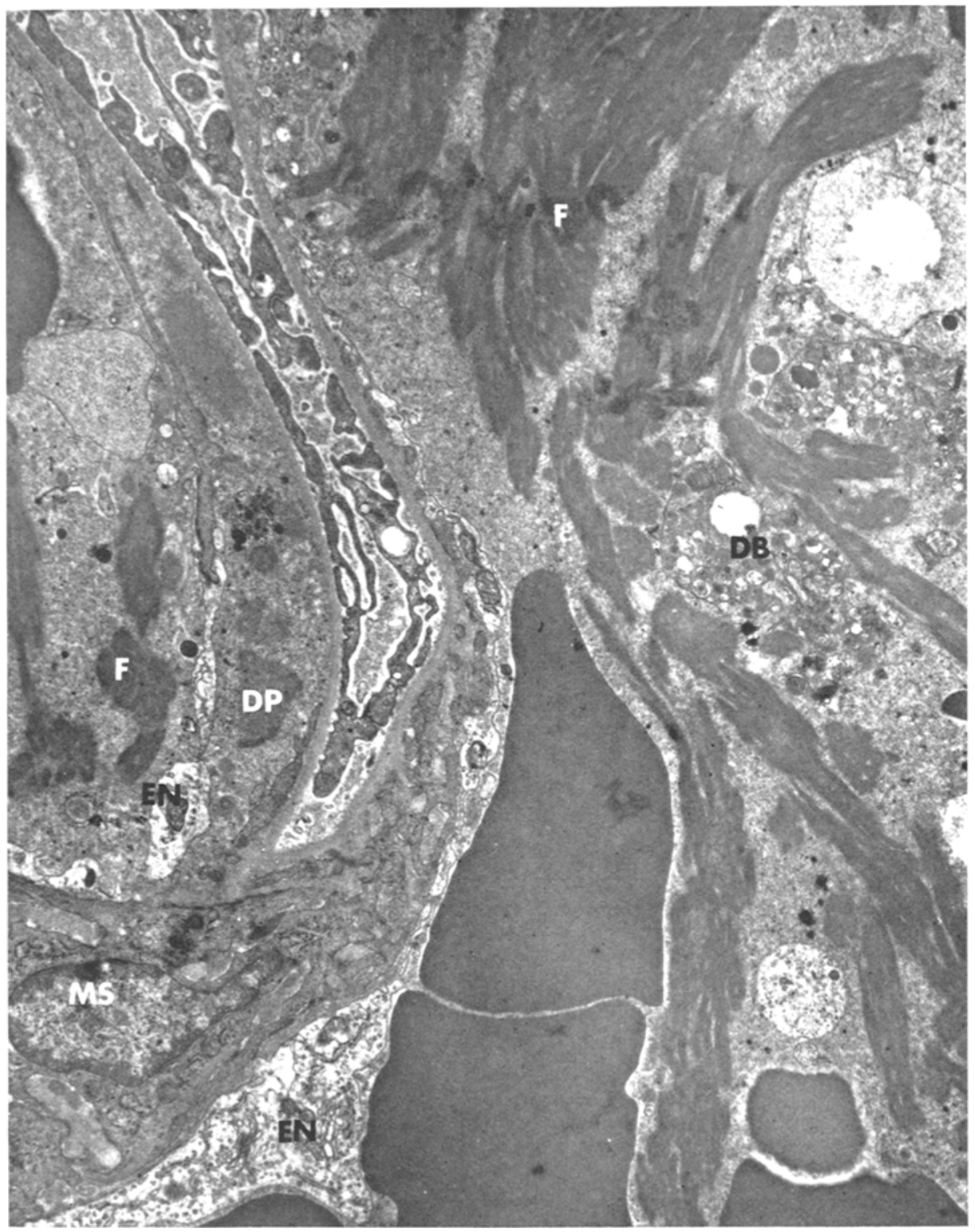

Fig. 9. $24 \mathrm{hr}$ after the injection. Massive fibrin formation (F) in the capillary lumen. Deposits $(D P)$ of fibrinoid material are seen beneath the endothelial cytoplasm $(E N)$. Mesangial cells (MS). Cell debris (DB). $9600 \times$

most striking in the glomerular capillary lumen, often clinging along glomerular basement membrane. The formation of fibrin thrombi was found most evident in 2 to 3 day biopsy specimens and also seen to persist for 2 to 3 weeks after the injection. The fibrin deposition and/or thrombotic changes in the early phase of Masugi nephritis were particularly noticed by Vassalli et al. (1964) with respect 
to its role in the development of glomerular changes. The acceleration of the blood coagulation might have been initiated by an early endothelial lesion caused by the nephrotoxic antibodies (Winemiller et al., 1961) or local release of some blood coagulation activator as a consequence of the antigen-antibody interaction. The massive deposition of fibrin and the persistence of thrombotic changes in glomeruli observed in the present study may be partly due to the weakness of the cellular reaction of neutrophiles and monocytes which have phagocytic-reparative effects in the primary phase of rat Masugi nephrltis, as has been suggested by Shigematsu (1970).

On the other hand, nephrotoxic $\operatorname{IgG}_{2}$ antibody which is capable of fixing complement had only a weak nephritogenicity at a comparable dose. Doses of over $30.6 \mu \mathrm{gN}$ of KFAbs caused death from pulmonary complications. Guinea pig $\mathrm{IgG}_{2}$ antibody in the preparation used may be lethal at nephrotoxic doses. It serves to confirm this possibility that the dose of lung fixing antibody in the $\mathrm{IgG}_{2}$ preparation is much more than that of kidney fixing antibody. Although the reason why the kidney fixed $\operatorname{IgG}_{2}$ antibody did not initiate complement mediated glomerular injury at a comparable dose is unexplained, it is suggested that non-complement mediated pathway may be of crucial importance in the initiation of at least some glomerular tissue injury.

The helpful advise and criticism of Drs. A. Okabayashi and Y. Kondo are gratefully acknowledged. We wish to express our thanks to Dr. K. Okuda for his review of this report.

\section{References}

Bale, W. F., Spar, I. L.: In vivo localization of rat organ antibodies in ovaries, adrenals and other tissues. J. Immunol. 73, 125-133 (1954)

Benacerraf, B., Ovary, Z., Bloch, K. J., Franklin, E. C.: Properties of guinea pig 7S antibodies. I. Electrophoretic separation of two types of guinea pig $7 \mathrm{~S}$ antibodies. J. exp. Med. 117, 937-950 (1963)

Bloch, K. J., Kourilsky, F. M., Ovary, Z., Benacerraf, B.: Properties of guinea pig 7S antibodies. III. Identification of antibodies involved in complement fixation and hemolysis. J. exp. Med. 117, 965-981 (1963)

Cochrane, C. G.: Immunologic tissue injury mediated by neutrophilic leucocytes. Advanc. Immunol. 9, 97-162 (1969)

Cochrane, C. G., Unanue, E. R., Dixon, F. J.: A role of polymorphonuclear leucocytes and complement in nephrotoxic nephritis. J. exp. Med. 122, 99-116 (1965)

Cole, L. R., Cromartie, W. J., Watson, D. W.: A specific soluble substance involved in nephrotoxic nephritis. Proc. Soc. exp. Biol. (N.Y.) 77, 498-501 (1951)

Day, E. D., Planinsek, J., Korngold, L., Pressman, D.: Tumor-localizing antibodies purified from antisera against Murphy rat lymphosarcoma. J. nat. Cancer Inst. 17 517-532 (1956)

Fujimoto, T., Okada, M., Kondo, Y., Tada, T.: The nature of masugi nephritis. Histo- and Immunopathological studies. Acta path. jap. 14, 275-310 (1964)

Hong, R., Palmer, J. L., Nisonoff, A.: Univalence of half-molecules of rabbit antibody. J. Immunol. 94, 603-610 (1965)

Imai, Y., Sue, A., Yamaguchi, A.: A removing method of the resin from epoxy-embedded section for light microscopy. J. Electron Microscopy 17, 84-85 (1968)

Kabat, E. A., Mayer, M. M.: Experimental immunochemistry (2nd ed), p. 133. Springfield: Thomas 1961

Keller, H. U., Nussenzweig, V., Sorkin, E.: Studies on chemotaxis. VIII. The role of 7S $\gamma 1$ and $\gamma 2$ guinea pig antibodies for chemotaxis in granulocytes. Immunochemistry 5, 293-295 (1968) 
Kourilsky, F. M., Bloch, K. J., Benacerraf, B., Ovary, Z.: Properties of guinea pig 7S antibodies. V. Inhibition by guinea pig $\gamma 1$ antibodies of passive immune lysis provoked by $\gamma^{2}$ antibodies. J. exp. Med. 118, 699-709 (1963)

Kunkel, H. G.: Zone electrophoresis. Meth. biochem. Anal. 1, 140-170 (1954)

Mardiney, M. R., Müller-Eberhard, H. J.: Mouse $\beta 1$ c-globulin: Production of antiserum and characterization of the complement reaction. J. Immunol. 94, 877-882 (1965)

Osler, A. G., Oliveira, B., Shin, H. S., Sandberg, A. L.: The fixation of guinea pig complement by $\gamma 1$ and $\gamma 2$ immunoglobulins. J. Immunol. 102, 269-271 (1969)

Ovary, Z., Benacerraf, B., Bloch, K. J.: Properties of guinea pig 7S antibodies. II. Identification of antibodies involved in passive cutaneous and systemic anaphylaxis. J. exp. Med. 117, 951-964 (1963)

Rother, K., Rother, U., Vassalli, P., McCluskey, R. T.: Nephrotoxic serum nephritis in C'6-deficient rabbits. I. Study of the second phase of the disease. J. Immunol.98, 965-971 (1967)

Sandberg, A. L., Osler, A. G., Shin, H. S., Oliveira, B.: The biologic activities of guinea pig antibodies. II. Modes of complement interaction with $\gamma 1$ and $\gamma^{2}$ immunoglobulins. J. Immunol. 104, 329-334 (1970)

Scheidegger, J. J.: Une micro-methode de I'mmunoelectrophorese. Int. Arch. Allergy 7, 103-110 (1955)

Shigematsu, H.: Glomerular events during the initial phase of rat Masugi nephritis. Virchows Arch. Abt. B 5, 187-200 (1970)

Shigematsu, H., Kobayashi, Y.: Pulmonary involvements in the initial phase of rat Masugi nephritis. Virchows Arch. Abt. B 11, 111-123 (1972)

Unanue, E. R., Dixon, F. J.: Experimental glomerulonephritis. IV. Participation of complement in nephrotoxie nephritis. J. exp. Med. 119, 965-982 (1964)

Unanue, E. R., Dixon, F. J.: Experimental glomerulonephritis. V. Studies on the interaction of nephrotoxic antibodies in tissues of the rat. J. exp. Med. 121, 697-714 (1965)

Unanue, E. R., Mardiney, M. R., Dixon, F. J.: Nephrotoxic serum nephritis in complement intact and deficient mice. J. Immunol. 98, 609-617 (1967)

Winemiller, R., Steblay, R. W., Spargo, B.: Electron microscopy of acute antibasement membrane serum nephritis in rats. Fed. Proc. 20, 408-408 (1961)

Wood, B. T., Thompson, S. H., Goldstein, G.: Fluorescent antibody staining. III. Preparation of fluorescein isothiocyanate-labeled antibodies. J. Immunol. 95, 225-229 (1965)

Vassalli, P., McClaskey, R. T.: The pathogenic role of the coagulation process in rabbit Masugi nephritis. Amer. J. Path. 45, 653-677 (1964)

Yagi, Y., Maier, P., Pressman, D.: Two different anti-insulin antibodies in guinea pig antisera. J. Immunol. 89, 442-451 (1962)

Y. Kobayashi, M. D.

School of Medicine

Kitasato University

Sagamihara

Kanagawa

Japan 